\title{
ADMISSIBILIDADE DA QUEBRA DO SIGILO DO WHATSAPP NA INVESTIGAÇÃO CRIMINAL: À LUZ DO PRINCÍPIO DA PRIVACIDADE
}

\author{
ADMISSIBILITY OF WHATSAPP \\ CONFIDENTIALITY BREACH IN \\ CRIMINAL INVESTIGATION IN THE \\ LIGHT OF THE PRIVACY PRINCIPLE
}

\section{Débora Motta ${ }^{1}$}

Resumo: A presente pesquisa busca analisar a quebra do sigilo, relativo ao uso do aplicativo WhatsApp, na prática das condutas criminosas, verificando a interpretação extensiva das normas jurídicas realizada por meio dos aplicadores da lei, devido à ausência de norma regulamentadora própria que aborde a questão criminal das novas tecnologias comunicacionais. Desse modo, busca-se verificar a possibilidade da aplicação das leis vigentes, criadas sem prever o avanço descontrolado da tecnologia ou seu uso como ferramenta da criminalidade, como explorar a admissibilidade de aplicação análoga a situações concretas semelhantes, mas substancialmente diversas. Além disso, verificar os entendimentos jurisprudenciais sobre a temática da quebra de sigilo, informações e dados do referido aplicativo, bem como apresentar indícios de consequências a violação dos direitos constitucionais e os limites da atuação Estatal na busca de elementos probatórios. Trata-se de pesquisa bibliográfica, realizada sobre o método dedutivo, pautada em fundamentação doutrinária, aplicação da legislação especial que trata da interceptação telefônica e entendimentos jurisprudenciais, notadamente em julgados dos tribunais, especialmente o Tribunal de Justiça catarinense e os Tribunais Superiores, fazendo uma análise dos principais entendimentos e discordâncias existentes.

Palavras-chave: Comunicação. Sigilo. Privacidade. Lei n. 9.296/96. WhatsApp.

Abstract: This research seeks to analyze the breach of confidentiality regarding the use of the WhatsApp application in the practice of criminal conduct, verifying the extensive

1 Bacharel em Direito pela Universidade do Oeste de Santa Catarina (Unoesc), Campus de Joaçaba-SC. E-mail: deboramottadto@outlook.com. 
interpretation of legal rules by law enforcers, due to the absence of its own regulatory rule that addresses the criminal of the news communication technologies. Thus, we seek to verify the possibility of applying the existing laws, created without foreseeing the uncontrolled advance of technology or its use as a tool of crime, as well as exploring the admissibility of analogous application to similar but substantially different concrete situations. In addition, it seeks to verify the jurisprudential understandings on the subject of breach of confidentiality, information and data of the said application, as well as presenting evidence of consequences of violation of constitutional rights and the limits of state action in the search for evidence. For the elaboration of the work, a bibliographic research was used, using the deductive method, from the doctrinal one, the application of the special legislation that deals with the telephone interception and jurisprudential understandings, notably those Courts of the Santa Catarina and Superior Courts, and an analysis of the main existing understandings and disagreements on the subject.

Keywords: Communication. Secrecy. Privacy. Law no 9.296/96. WhatsApp.

\section{INTRODUÇÃO}

Desde a globalização a tecnologia passou a conquistar seu espaço. De forma acelerada, o avanço tecnológico atingiu todas as esferas sociais, ideológicas, etárias, econômicas, expandindo-se e fixando raízes, tornando-se um item indispensável ao funcionamento da vida humana.

Naturalmente, com o desenvolvimento da sociedade e, agora, com o acelerado avanço da tecnologia, os entendimentos, ideologias e informações surgem rapidamente, alteram-se, fundem-se, extinguem-se, ou simplesmente, passam a ter interpretações diversas, de acordo com o momento em que são acessadas. Assim, a partir da promulgação da Constituição Federal de 1988, muitos direitos foram garantidos, interpretações foram alteradas e, principalmente, a tecnologia passou a fundir-se e guiar a vida em sociedade, tomando espaços sociais, pessoais e profissionais, influenciando - potencialmente a educação e o acesso ao conhecimento.

Em face dessa atualização tecnológica e comunicacional, a legislação já vigente não abordou explicitamente a existência 
das novas tecnologias e seus acessórios, forçando aos aplicadores do direito fazerem uso de novas estruturas normativas, muitas vezes, por meio da aplicação extensiva, para lidar com os riscos e as oportunidades trazidas pelas inovações. Assim, em decorrência das aplicações analógicas e do vasto campo jurídico em que a sociedade está inserida, surgem entendimentos antagônicos que, muitas vezes, entram em conflitos com os direitos fundamentais garantidos.

Ressalta-se que, dentre os principais avanços comunicacionais presentes neste século, especialmente entre os brasileiros, se encontra o uso do aplicativo WhatsApp, uma vez que, devido à vida atribulada e cheia de compromissos, obtém-se informações de forma voraz, por meio de aparelhos que substituem os computadores e notebooks, atendendo inúmeras funções, geralmente, com apenas um clique, perdendo-se a necessidade da comunicação falada, preferindo escrever rapidamente com dados acessados imediatamente pelo receptor, quebrando as barreiras das distâncias, bem como evitando, em suma, que terceiros saibam da mensagem a ser transmitida.

Nesse sentido, devido ao sigilo que é prometido e proporcionado pelo aplicativo, os usuários se sentem seguros para conversar, comprar, trocar informações profissionais, educacionais e sigilosas. Além disso, o sigilo das comunicações é garantido previamente pela Lei maior, possuindo os nacionais e quem quer que esteja no território brasileiro, garantia de não ter esta parcela de intimidade infringida.

Todavia, apesar do direito existir desde a concepção da ideia de Estado, o homem continua violando as regras sociais e privando terceiros das liberdades e direitos a si garantidos em nossa Constituição. Assim, permanece a existência do crime como uma natureza própria do homem, desrespeitando o contrato social e ferindo o patrimônio, a liberdade e a vida dos demais.

Dessarte, a existência do crime adequa-se a moral, a cul- 
tura, ao momento histórico e, sobretudo, aos avanços tecnológicos enraizados na sociedade. De forma proporcional, apesar da descoberta do fato criminoso, que fere os direitos Constitucionais, ser de interesse público, nota-se que inclusive o criminoso, incondicionalmente, possui direitos fundamentais que devem ser respeitados pela sociedade e pelo ente Estatal. Desse modo, não poderá a lei ser relativizada pelo prazer dos juízes, membros do Ministério Público, das autoridades policiais, dos servidores da justiça, ou simplesmente, atender os anseios de segurança dos terceiros lesados.

Portanto, o presente estudo busca, por meio da utilização da doutrina, de normas legislativas e de entendimentos jurisprudenciais, delimitar a possibilidade de obtenção de dados, provenientes do aplicativo WhatsApp, diretamente no aparelho celular do investigado e seu uso como prova no âmbito criminal.

\section{ADMISSIBILIDADE DA QUEBRA DE SIGILO}

Precipuamente, nos últimos anos, o avanço crescente do aplicativo WhatsApp, viabilizou o acesso a informações e alterou a forma das pessoas se comunicarem. Contudo, dentre os usuários que utilizam essa ferramenta, há aqueles que ferem o ordenamento jurídico utilizando o fácil acesso comunicacional na realização de atos criminosos.

De maneira geral, para o acesso das informações trocadas por essas pessoas, que objetivam ilícitos, não é possível obter as informações por meio da empresa ou realizando, em tese, uma interceptação telefônica propriamente dita, pois além do sigilo das informações existe o fato da comunicação, geralmente, ser escrita.

É importante frisar que, a quebra de sigilo realizada diretamente no aparelho apreendido deve ter sua forma procedimental regida com respaldonas leis vigentes aplicáveis no ordenamento pátrio. Que, apesar de não terem sido criadas para 
atendê-la, é a legislação mais adaptável para regular a quebra de sigilo do aplicativo WhatsApp.

Ante o exposto, é necessário contextualizar os direitos dos usuários que utilizam o aplicativo, verificando a possibilidade de relativização dos direitos e garantias, bem como a maneira pela qual será realizada sua quebra, objetivando manter a validade e admissibilidade nos autos criminais, de acordo com as regras vigentes no ordenamento jurídico brasileiro.

\subsection{Garantias constitucionais e sua relativização}

Inicialmente, Sarlet $(2015$, p.438) traz como direito basilar para a proteção da dignidade humana o crivo do direito à privacidade, que, apesar de nem sempre ter sido tratado expressamente nas Constituições Pátrias anteriores, sem dúvida, é um direito de extrema importância para as pessoas, sendo garantido pela atual Constituição Federal, promulgada em 1988. Ademais, o expresso reconhecimento da vida privada desenvolve-se em convergência com os demais direitos fundamentais constitucionais, como a intimidade, inviolabilidade de domicílio e das comunicações.

Nesse sentido, convém frisar que os referidos direitos são essenciais à saúde mental do ser humano, pois lhe asseguram condições para o livre desenvolvimento da sua personalidade. (SARLET, 2015, p. 439).

Ademais, devido ao fato de os aludidos direitos associarem-se diretamente à dignidade da pessoa humana, o indivíduo possui autonomia da vontade e livre-arbítrio, pois "[...] o direito à privacidade confere ao indivíduo a possibilidade de conduzir sua própria vida da maneira que julgar mais conveniente, sem intromissão da curiosidade alheia, desde que não viole a ordem pública, os bons costumes e os direitos de terceiros". (NOVELINO, 2015, p. 409).

Embora se busque traçar uma distinção entre o direito da 
privacidade e da intimidade, a fluidez existente entre as diversas esferas da vida privada não a torna clara e completa. Assim, de acordo com Sarlet (2015, p. 439) e Novelino (2010, p. 410), utiliza-se como referência a "Teoria das Esferas", adotada pela jurisprudência e doutrina alemã, na qual pode se estabelecer uma variação de grau de proteção à privacidade, de acordo com a personalidade afetada. Desse modo, ambos doutrinadores concordam com a existência de uma esfera íntima: na qual o núcleo essencial é intangível, pois trata do modo de ser do um indivíduo.

Em relação às outras esferas da vida privada, há uma discordância conceitual entre os doutrinadores. Sarlet (2015, p. 439-440) alega a existência da esfera privada, compostos por aspectos não sigilosos, sendo possível a ponderação em relação a outros bens jurídicos; e, a esfera social, na qual se situam os direitos da imagem e da palavra.

Por sua vez, Novelino (2010, p. 409-410) entende que existe uma esfera da publicidade, em que os atos praticados são realizados em locais públicos com o desejo de torná-los transparentes; uma esfera pessoal que abrange as relações com o meio social, sem existir a vontade ou interesse na sua publicidade ou na sua divulgação; e por fim, a esfera privada que compreende os dados relativos a situações de maior proximidade pessoal.

Devido aos seus sentidos diversos, sem logro de definir com precisão o direito à privacidade, ratifica-se que é possível identificar a existência de parâmetros, alguns mais no âmbito aberto, outros no âmbito íntimo, permitindo sua aplicação, desde que haja ponderação. Assim "a violação do direito à privacidade somente poderá ser adequadamente aferida à luz das circunstâncias do caso concreto". (SARLET, 2015, p. 440).

Segundo o que estabelece o art. $5^{\circ}$, inciso X, da Constituição Federal (BRASIL, 1988), "são invioláveis a intimidade, 
a vida privada, a honra e a imagem das pessoas, assegurado o direito a indenização pelo dano material ou moral decorrente de sua violação".

Nesse aspecto, é importante frisar que o referido direito assegura a garantia de viver sem a constante interferência do Estado ou de terceiros, no que toca aos aspectos da vida pessoal e familiar. Portanto, o indivíduo encontra-se no controle das informações que lhe dizem respeito, pois são informações atinentes a sua vida pessoal. (SARLET, 2015, p.440). Ou seja, "o direito à privacidade consiste num direito a ser deixado em paz [...] na proteção de uma esfera autônoma da vida privada, no qual o indivíduo pode desenvolver a sua individualidade [...], sem que ele seja compelido a determinados comportamentos [...]”. (SARLET, 2015, p. 441).

Além do mais, a esfera de privacidade possui conexão com o princípio da proporcionalidade, a qual sofrerá variações de acordo com o âmbito em que estiver inserida. Assim, quanto o âmbito é aberto, é possível existir uma intervenção do Estado, desde que ocorra a observação dos critérios da proporcionalidade no caso concreto e busque salvaguardar outros direitos fundamentais constitucionalmente assegurados. (SARLET, 2015, p. 441).

Nesse bojo particular, é oportuno esclarecer que o "direito à privacidade não se revela ilimitado e imune a intervenções restritivas". (SARLET, 2015, p. 443). Em outras palavras, devido ao fato da Constituição não delimitar expressamente a abrangência dos direitos relativos à privacidade e à intimidade, ambas receberam um elevado grau de proteção, permitindo que sua relativização ocorra apenas em casos restritos, de forma justificada e sob a necessidade de assegurar outros direitos fundamentais constitucionalmente protegidos. Isto é, jamais se reduzirá os presentes direitos a ponto de extingui-los ou menosprezá-los, mas é possível mitigá-los proporcionalmente para atender outros direitos assegurados. Assim, consagra-se o entendimento da 
relativização dos mencionados direitos, desde que, em determinadas situações, para atender a supremacia do interesse público em detrimento da privacidade do ser individual.

No entendimento em apreço, estabelece o art. $5^{\circ}$, inciso XII, da Constituição Federal (BRASIL, 1988) que o sigiloatinente às correspondências e as comunicações telegráficas, telefônicas e de dados são invioláveis pela lei constitucional, salvo em relação a comunicação telefônica em que se poderá ocorrer a quebra de sigilo, objetivando atender investigação criminal ou determinada instrução processual penal.

A Carta Magna, ao tornar o presente sigilo inviolável, buscou proteger do crivo da intervenção Estatal o conteúdo da mensagem transmitida, haja vista a proteção dispendida pela privacidade sobre seu acesso. (NOVELINO, 2010, p. 417). Dessa forma, toda a informação produzida pelo indivíduo deverá estar protegida do acesso e conhecimento de terceiros, seja correspondência (carta, e-mail), comunicação telegráfica ou de dados (mensagens, aplicativos de mensagem).

Ademais, esclarece Branco (2015, p. 293) que "A quebra da confidencialidade da comunicação significa frustrar o direito do emissor de escolher o destinatário do conteúdo de sua comunicação". Isto é, a conversa deixa de ser privada, tornando-se pública a terceiro alheios, violando a privacidade e o sigilo de receptor e destinatário.

Assim sendo, a violação do sigilo de uma correspondência poderá ser admitida tanto quando estiverem pauta questões de segurança pública, quanto na utilização como instrumento para descoberta e provas para condenação de práticas ilícitas. (NOVELINO, 2010, p. 417). Desse modo, defende Nucci (2016, p.508) que não há direito ou garantia fundamental de caráter absoluto, desde que a violação ocorrida por qualquer forma de interceptação seja autorizada por ordem judicial, para fins de 
investigação e processo criminal.

Por tal motivo, foi criada a Lei n. 9.296 (1996), conhecida como Lei de Interceptação Telefônica, objetivando regulamentar a aplicação do art. $5^{\circ}$, inciso XII, da Constituição Federal, a qual será devidamente abordada no tópico 2.3.

Por conseguinte, com o surgimento da Lei do Marco Civil da Internet (Lei n. 12.965/2014), em 23 de abril de 2014, passou-se a regular as matérias relativas aos equipamentos, acessórios e aplicativos que utilizam a internet na comunicação, principalmente na troca de dados e informações, garantindo a inviolabilidade do fluxo de comunicações via internet, bem como as mensagens privadas nele armazenadas. Entretanto, acitada lei não trouxe previsão quanto à relativização dos direitos, nem definiu regras próprias ou limites aplicáveis à obtenção de informações, sejam dados dos usuários ou proveniente das conversas via internet, cabendo sua relativização ser motivada em outra base legal. (GONÇALVES, 2017).

Igualmente, observando o aplicativo de comunicação WhatsApp sobre o prisma da legislação atual, pautada no conceito trazido pelo art. $7^{\circ}$ do Marco Civil da Internet, é visível a impossibilidade da empresa gestora realizar o bloqueio e a quebra de informações de seus usuários, devido à criptografia existente nas mensagens, sendo incabível a realização da interceptação para se ter acesso às mensagens entre o transmissor $\mathrm{e}$ o receptor. (BRASIL, 2014).

Dessa maneira, ante a impossibilidade da interceptação propriamente dita, resta aos órgãos responsáveis pela persecução penal realizar a quebra de sigilo diretamente no aparelho apreendido, devendo sua forma procedimental ser regida de acordo com as leis vigentes aplicáveis as situações concretas, isto é, aplicar a legislação mais adaptável à quebra de sigilo do aplicativo WhatsApp. 
Diante deste contexto e em virtude das dimensões constitucionais presentes nas demais normas infraconstitucionais, é possível verificar que, apesar da privacidade dos usuários dos serviços de mensagem, de comunicação via internet, bem como o sigilo existe neste fluxo comunicacional ser o principal objetivo do Marco Civil da Internet, existe a possibilidade de quebrar o sigilo por ordem judicial, ou seja, por meio da Lei n. 9.296/96 ou Lei de Interceptação Telefônica, a qual requer necessariamente autorização judicial prévia para ser efetuada. (GONÇALVES, 2017).

Devido a esta aplicação análoga, é necessário verificar em que contexto se encaixa os aplicativos com uso da internet, como é o caso do aplicativo WhatsApp, verificando qual é sua conceituação e definição, haja vista que este conhecimento determina como deverá ocorrer a obtenção ou colheita de provas, sua validade, valor probatório e até mesmo quais os valores fundamentais da pessoa humana que são violados.

\subsection{Admissibilidade das provas obtidas}

Intimamente ligado às questões anteriores, há teorias processuais que estudam a admissibilidade das provas.

Nesse campo, traz Lopes Junior (2008, p. 548-549) a Teoria das Provas Ilícitas, dispondo a possibilidade da Admissão da Prova ilícita, quando não for vedada pelo ordenamento processual. Esta posição que não possui guarida na jurisprudência Brasileira, pois um objeto, em uma mesma situação, poderá ser considerado ilícito e, também, perfeitamente válido para gerar efeitos no Processo Penal.

Além disso, há a teoria da inadmissibilidade absoluta, defendida pelos juristas que realizam uma leitura literal do disposto no art. $5^{\circ}$, inciso LVI, da Carta Política. Esta teoria se pauta na completa vedação da relativização, vindo de encontro à própria Constituição, que nega o caráter absoluto de regras e direitos, o qual se verifica na possibilidade de quebra de dados 
e interceptações telefônicas, bem como na limitação das garantias quando interferem em outros direitos constitucionais. (LOPES JUNIOR, p. 549-550).

Ainda, Lopes Junior (2008, p. 550) expõe que a teoria da admissibilidade da prova ilícita em defesa do princípio da proporcionalidade poderá instituir um risco, pois constitui um conceito genérico, sendo possível a influência de alguma pessoa, principalmente, ao elencar a relevância do interesse público sobre o interesse privado.

Por fim, consta a admissibilidade da prova ilícita "pro reo", admitindo sua valoração apenas se for favorável ao réu. De acordo com Lopes Junior (2008, p. 553), esta teoria serve como um instrumento a serviço da máxima eficácia dos direitos e garantias fundamentais.

Assevera Oliveira $(2015$, p. 354$)$, em relação à relativização dos direitos, que se o próprio direito à vida, bem e valor maior de todo indivíduo, do qual derivam os demais direitos, possui limites dispostos na lei, os demais direitos também poderão ser limitados, mesmo não tendo sido previsto qualquer tipo de proposição nos vernáculos da lei.

Além das hipóteses apresentadas, Oliveira (2015, p. 363) apresenta a Teoria dos Frutos Envenenados, o qual tem origem na doutrina norte-americana e atribui uma consequência lógica ao uso das provas ilícitas. Assim, o uso de uma prova considerada ilícita poderá desencadear a ilicitude de todas as provas que decorrerem da primeira, a qual foi considerada ilícita. Isto é, se a prova original é ilícita, todas as provas dela derivada também serão ilícitas. A presente teoria, desde 2008, passou a vigorar no ordenamento jurídico brasileiro, no art. $157, \S 1^{\circ}$, do Código de Processo Penal.

Desse modo, com base na referida teoria, caso ocorra a violação de um direito fundamental obtendo-se uma prova 
ilícita e, apesar desta ser considerada como moralmente justa ao interesse público, não poderá ser aproveitada. Infelizmente, seu uso poderá acarretar a nulidade das demais provas que dela tenham se originado.

De tal modo, apesar do surgimento do Marco Civil da Internet e sua aplicação ajustar-sena regulamentação de matéria relativa a equipamentos, acessórios e aplicativos que utilizam a internet na comunicação ou que efetivem troca de dados e informações, a quebra da inviolabilidade do sigilo deverá ser realizadapor meio da aplicação de Lei de Interceptação Telefônica, pois a Lei n. 12.965/14 não definiu regras próprias ou limites aplicáveis à obtenção de informações, sejam dados dos usuários ou das conversas via internet, devendo ocorrer analogia e interpretação extensiva da Lei n. 9.296/96, objetivando abranger e solucionar situações diversas, não previstas por ambas as leis quando das suas criações.

É importante verificar, antes de constatar a admissibilidade da prova, o contexto em que se encaixa o aplicativo de internet WhatsApp, conferindo-lhe conceituação e definição, para que, a partir desse conhecimento, se determine como deve ocorrer o acesso e a colheita das informações, para manter a validade e valor probatório no campo das provas processuais penais.

Nesse sentido, enaltece a Corte de Justiça catarinense que não há quebra de sigilo telefônico, pois o aplicativo WhatsApp configura um banco de dados, em que há um acúmulo de mensagens que interessam ao processo penal. Assim, não existirá nulidade na prova obtida sem autorização judicial, pois trata-se meramente de dados. (BRASIL, 2016a).

Entretanto, alguns doutrinadores, como é o caso de Lima (2016), entendem que o aplicativo configura uma forma de comunicação telefônica e, dessa maneira, deverá ser regida como se assim fosse, permitindo a aplicação da Lei n. 9.296/96, ou 
seja, acesso apenas mediante prévia autorização judicial.

É importante frisar que o entendimento firmado pelo Superior Tribunal de Justiça (STJ) quanto a obtenção de provas, por meio do acesso aos arquivos e dados contidos no aparelho celular, sem prévia autorização, eiva as provas colhidas, tornando-as ilícitas, devendo essas seremdesentranhadas dos autos (BRASIL, 2017a).

Ademais, com a vigência do Marco Civil da Internet, Lei n. 12.965/2014, passa-se a entender, analogicamente, que o aplicativoWhatsApp é inviolável, tanto em relação ao fluxo de comunicações ocorridas por meio da internet, quanto as informações privadas armazenadas no aparelho dele provenientes, devendo ambos os casos terem o sigilo quebrado por meio da Lei n. 9.296/96. (GONÇALVES, 2017).

Verifica-se, ainda, de acordo com o Informativo n. 593 do Superior Tribunal de Justiça, que, caso ocorra a prisão em flagrante e seja dispensável ordem judicial para a apreensão de telefone celular, as mensagens armazenadas no aparelho estão protegidas pelo sigilo telefônico, compreendendo igualmente a transmissão, recepção ou emissão de símbolos, caracteres, sinais, escritos, imagens, sons ou informações de qualquer natureza, por meio de telefonia fixa ou móvel ou, ainda, por meio de sistemas de informática e telemática. (BRASIL, 2016b).

Em consonância ao informativo acima, a $5^{\text {a }}$ (quinta) Turma do Superior Tribunal de Justiça reconheceu a ilegalidade de provas obtidas pela polícia, sem autorização judicial, de mensagens arquivadas no aplicativo WhatsApp e determinou sua retirada dos autos. Esclarece a Corte que deveria a autoridade policial, após a apreensão do telefone, ter requerido judicialmente a quebra do sigilo dos dados armazenados, haja vista a garantia à inviolabilidade da intimidade e da vida privada. (BRASIL, 2017b).

Entretanto, de acordo como o julgamento do RHC 77.232/ 
SC, apreciado em outubro de 2017, pela $5^{\text {a }}$ (quinta) Turma do Superior Tribunal de Justiça, a autorização de busca e apreensão no domicílio do investigado, com a finalidade de apreender instrumentos utilizados na prática de crime ou destinados a fim delituoso, além de permitir a colheita de outros elementos de convicção, não obsta o acesso pela autoridade policial do conteúdo armazenado no aparelho móvel, incluindo as conversas do aplicativo WhatsApp. Assim sendo, é desnecessária nova autorização judicial para acesso dessas informações, pois a determinação de busca e apreensão é suficiente para permitir o acesso aos dados dos aparelhos celulares apreendidos, inclusive as informações salvas no aplicativo WhatsApp. (BRASIL, 2017c).

Ante o exposto, verifica-se a existência de divergências jurisprudências nas instâncias superiores, existindo entendimentos, firmado pelo Tribunal de Justiça de Santa Catarina, que o aplicativo WhatsApp é um banco de dados, sendo desnecessária intervenção judicial para seu acesso. Em contrapartida, o Superior Tribunal de Justiça entende que o aplicativo configura um sistema comunicacional, sendo necessário, sob pena de nulidade, a prévia autorização judicial.

\subsection{Lei n. 9.296/96 - Interceptação Telefônica}

Uma das principais formas de efetivar o direito a privacidade ocorre, muitas vezes, pela garantia e cumprimento do sigilo das comunicações.

No entendimento em apreço, estabelece o art. $5^{\circ}$, inciso XII, da Constituição Federal (BRASIL, 1988) que "é inviolável o sigilo da correspondência e das comunicações telegráficas, de dados e das comunicações telefônicas, salvo, no último caso, por ordem judicial, [...] para fins de investigação criminal ou instrução processual penal".

Por tal motivo, foi criada a Lei n. 9.296, de 24 de julho de 1996, conhecida como Lei de Interceptação Telefônica, objeti- 
vando estabelecer limites à aplicação de interceptação ao fluxo de comunicações em sistemas de informática e telemática, conforme dispõe o art. $1^{\circ}$ da referida lei. (BRASIL, 1996).

Com efeito, dispõem os arts. $4^{\circ}$ e $5^{\circ}$ da mencionada Lei, que o pedido de interceptação de comunicação telefônica deverá demonstrar a necessidade de sua realização, bem como a decisão deverá ser fundamentada e específica, sob pena de nulidade. (BRASIL, 1996).

Assim, é possível observar que a quebra do sigilo avaliará pontos específicos, não sendo realizado a todo o momento e por qualquer motivo, mas por indícios que embasaram a decisão do juízo.

Com a leitura do preceito constitucional e a criação da lei para regulamentar o inciso XII, parte final, do art. $5^{\circ}$ da Constituição Federal, conclui-se que a interceptação telefônica só poderia ocorrer em relação aos casos de comunicação telefônica, sendo impossível quebrar o sigilo em relação aos dados constantes nas correspondências postais, telegráficas e comunicações telemáticas. (BRANCO, 2015, p.293).

Entretanto, a jurisprudência e a doutrina entendem que não há direitos absolutos, sequer as de correspondência e comunicação telemática, podendo ocorrer a restrição dos direitos fundamentais, sem autorização do constituinte, desde que o caso seja respeitado pelo princípio da proporcionalidade. (BRANCO, 2015, p. 293).

Desse modo, a aplicação da Lei de Interceptação Telefônica estende-se às comunicações telegráficas e de dados e às correspondências, devendo o sigilo ser mantido e o acesso as informações protegidas ser autorizada apenas se preenchidos os critérios do princípio da proporcionalidade, isto é, a quebra do sigilo deverá ocorrer, somente, após prévia autorização judicial devidamente motivada. 
O Supremo Tribunal Federal (STF) entendeu, no HC 91.867, publicado no Diário da Justiça Eletrônico em 20 de setembro de 2012, contando como relator Ministro Gilmar Mendes, que o sigilo garantido no preceito fundamental art. $5^{\circ}$, inciso XII, da Constituição Federal faz referência à comunicação de dados e não dos dados propriamente ditos, pois há proteção jurídica concedida é distinta para a comunicação telefônica e para os registros telefônicos. (BRANCO, 2015, p. 294).

Assim, a quebra de sigilo mostra-se como medida excepcional, devendo ser realizada apenas quando não verificada nenhuma hipótese prevista no art. $2^{\circ}$ da Lei n. 9.296/96, ou seja, apenas quando a informação mostrar-se necessária para apurar ocorrência de ilícito, o delito tenha pena de reclusão, houver indícios razoáveis da autoria ou participação e a prova não possa ser obtida por outros meios, podendo ser requerida em qualquer fase do inquérito ou do processo judicial, conforme disposição do art. $3^{\circ}$ da Lei n. 9.296/96. (BRASIL, 1996).

Frisa-se que a quebra de dados, como na quebra do sigilo telefônico, é uma medida excepcional, só devendoser utilizada quando a materialidade do delitonão possa ser comprovada e obtida por meios diversos que não restrinjamos direitos fundamentais. Assim, atribui-se a função deavaliar cada caso concreto ao douto juízo, o qualanalisaráa existência dealternativas menos invasivas e lesivas aos direitos dos indivíduos. (CAPEZ, 2017).

Convém ressaltar que, na existência de outra escolha probatória deve-se ela utilizar, mas, se o meio alternativo mostrar-se de extrema dificuldadede produção, a autorização judicial poderá ser concedida. (CAPEZ, 2017).

Em virtude do exposto, a conduta vedada pelo ordenamento jurídico, em tese, não é o acesso dos dados, mas realizar a quebra do sigilo, permitindo o "vazamento" de seu conteúdo. Em outras palavras, com a quebra do sigilo, se obtém informa- 
ções que, anteriormente, eram privadas, de conhecimento apenas do emissor e do receptor. Entretanto, efetuada a quebra da confidencialidade, o conteúdo passa ser acessado por terceiros alheios à comunicação, de forma que as informações obtidas sejam utilizadas, principalmente, se demonstrarem ser úteis para a revelação da verdade real dos fatos ilícitos cometidos.

Portanto, é permitida a realização da quebra de sigilo, utilizando como base a Lei n. 9.296/96, devendo ocorrer o prévio requerimento, sendo concedida mediante decisão judicial devidamente fundamentada e motivada.

\subsection{Casos concretos e sua aplicação jurídica}

Neste momento, passa-se a análise das decisões jurisprudenciais existentes nos Tribunais, verificando as decisões formadas pelos desembargadores e ministros no exame da temática.

Inicialmente, traz ao crivo o divisor de águas, que trouxe uma nova forma de avaliar a licitude dos dados obtidos dos aparelhos de telefonia móvel, os quais carregam o aplicativo comunicacional conhecido por WhatsApp.

O referido marco ocorreu em maio de 2016, quando a Sexta Turma do Superior Tribunal de Justiça, no julgamento do Recurso de Habeas Corpus n. 51.531/RO, tendo como relator o Ministro Cordeiro, consignou na ementa, que "ilícita é a devassa de dados, bem como das conversas de WhatsApp, obtidas diretamente pela polícia em celular apreendido no flagrante, sem prévia autorização judicial".(BRASIL,2016c).

Explica o relator em seu voto que, no caso fático, ocorreu a perícia e o acesso dos dados armazenados no telefone móvel, incluindo as conversas realizados por meio do aplicativo What$s A p p$, sem ter a autoridade policial obtido ordem judicial para o seu acesso. Apontou que houve "devassa de dados particulares, com violação à intimidade do agente”. (BRASIL, 2016c). 
Ainda, segundo o Cordeiro (BRASIL, 2016c), embora haja a possibilidade do acesso, é necessária a prévia autorização judicial devidamente motivada. Afirma ainda que, o programa WhatsApp é uma forma de comunicação escrita, imediata, entre interlocutores, devendo a interceptação da comunicação não ser autorizada. Além disso, compara a conversa pelo aplicativo a uma conversa por e-mail, cujo acesso somete se dá com prévia ordem judicial.

Em 2017, a Corte de Justiça catarinense, por meio da relatora Desembargadora Sommariva, entendeu que houve ilicitude na prova obtida em fase inquisitorial, nos autos de em prisão em flagrante de tráfico de drogas ocorrido na $1^{\circ}$ Vara da Comarca de Criciúma, afrontando previsão constitucional, devido devassa de mensagens de texto do aplicativo WhatsApp, dados esses protegidos pelo sigilo das comunicações telefônicas. Devido à falta de autorização judicial, seu acesso e visualização tornou a prova obtida em prova nula.

Ainda, a relatora expôs que as provas colhidas nos autos foram visualizadas pelos policiais militares e civis sem prévia autorização. Embora as mensagens contidas no celular do acusado, referentes ao trafico ilícito de entorpecentes, tenham sido obtidos em situação de flagrância, seu conteúdo é protegido por sigilo. (BRASIL, 2018a).

Do mesmo modo, já decidiu o Superior Tribunal de Justiça em Recurso de Habeas Corpus, que é possível a quebra de sigilo das comunicações, bem como as provas obtidas serão consideradas lícitas para fins de incriminação no Direito Penal, desde que observem as normas legais e prévia autorização judicial. (BRASIL, 2018b).

Nesse sentido, busca-se coibir a colheita de provas ilícitas pelo Estado que afetem os direitos fundamentais, como a intimidade, a privacidade, a inviolabilidade domiciliar e o sigilo das comunicações e, sobretudo, o direito de não se autoincri- 
minar ou de não fazer prova contra si mesmo, instituto consagrado no Pacto de São José da Costa Rica, internalizado no Brasil pelo Decreto n. 678/1992. (BRASIL, 2018b).

Ressalta-se que, o voto do mencionado julgado, reconheceu a ilicitude da colheita de dados dos aparelhos telefônicos, mediante conversas de WhatsApp, sema devida e prévia autorização, devendo as provas retiradas do aplicativos e as delas derivadas, serem desentranhadas dos autos, competindo ao Juízo de origem reanalisar o processo, verificando o nexo de causalidade e eventual existência de fonte independente, nos termos do art. 157, $\S 1^{\circ}$, do Código de Processo Penal. (BRASIL, 2018b).

Recentemente, a $6^{\text {a }}$ (sexta) Turma do Superior Tribunal de Justiça proveu recurso de réu preso, condenado pelo crime de tráfico de drogas, declarando nulas as provas obtidas pelo exame do celular, a partir de conversas do WhatsApp, do réu por autoridade policial. (BRASIL, 2018c).

Inicialmente, em defesa preliminar no juízo de $1^{\circ}$ grau não foi acolhida a tese sustentada de nulidade das provas. Por esse motivo, foi impetrado Habeas Corpus perante a Corte Estadual Paulista, todavia, houve a denegação da ordem, motivada no fato de não ter sido vislumbrada ilegalidade, pois o que "se protege é a comunicação dos dados, e não os dados que já estão armazenados". Ademais, com a prisão em flagrante do flagranteado, se apreenderam os objetos relacionados ao crime, os quais devem ser submetidos à perícia técnica, conforme art. $6^{\mathrm{o}}$, inciso II, do Código de Processo Penal. Isto é, para o Tribunal a quo, a prévia autorização judicial não é necessária para a realização de perícia no aparelho apreendido. Assim, com o flagrante, seria possível realizar a análise dos dados existentes no aparelho apreendido para buscar elementos aptos a esclarecer a autoria e materialidade do delito. (BRASIL, 2018c).

Depreende-se do inteiro teor do acordão de n. 89.395/SP que o Ministro Schietti Cruz considerou a prova ilícita, pois 
não é permitida no ordenamento jurídico e nem pode ingressar no processo, uma vez que é destituída de qualquer grau de eficácia jurídica, conforme dispositivo previsto na Constituição, estando o acórdão estadual confrontando a Jurisprudência doSuperior Tribunal de Justiça. (BRASIL, 2018c).

O ministro, no entanto, fez uma ressalva de que "não é possível declarar a ilicitude de todo o conjunto probatório" produzido nos autos, após a juntada do laudo pericial. Assim, será inadmissível apenas as provas derivadas das ilícitas que não demonstrem nexo de causalidade, e as derivadas que não forem obtidas por fonte independente, conforme previsão no art. 157, $\S 1^{\circ}$,do CPP. (BRASIL, 2018c).

Ante o exposto, verifica-se que ainda há divergências jurisprudenciais nos Tribunais Estaduais e nas Turmas do Superior Tribunal de Justiça, tanto na questão etimológica e de natureza do aplicativo WhatsApp, quanto em relação à quebra do sigilo. Contudo, verifica-se que, desde 2016, as decisões passaram em grande parte a ser contrárias às quebras de sigilo sem autorização.

Em decorrência disso, objetivando evitar que as provas obtidas sem autorização precisem ser desentranhadas dos autos, o melhor caminho a se seguir é requerer à autoridade judicial permissão para ao acesso, cabendo o julgador avaliar se estão presentes os motivos previstos na Lei n. 9.296/96 e fundamentar a decisão judicial.

\section{CONCLUSÃO}

Inicialmente, é importante concluir que o aplicativo WhatsApp passou de uma mera ferramenta de armazenamento de dados para um sistema comunicacional que atende muitos brasileiros, em todo o nosso vasto território.

Esse instrumento, que apesar de possuir simples utilização na vida privada dos seus usuários, enseja, ainda, complexos 
debates no campo jurídico, principalmente, por não se adequar plenamente as legislações já concebidas e enraizadas no nosso ordenamento jurídico.

Com isso, muito dos debates e das discordâncias existentes nas cortes superiores, seja de $2^{\mathrm{a}}$ ou superior instância, decorre das diversas concepções, de diferentes pessoas, que buscam adequar essa tecnologia conforme seus conhecimentos e pré-conceitos.

Por este motivo, levando em conta que a $2^{\mathrm{a}}$ instância catarinense estende que o aplicativo WhatsApp configura um banco de dados, e a instância superior entende que é uma forma comunicacional, deverão as futuras decisões serem tratadas com cautela, verificando os demais princípios atinentes a inviolabilidade das comunicações e à privacidade dos indivíduos.

Assim, a quebra de sigilo das comunicações, informações e dados privativos do aplicativo WhatsApp, em virtude de sua recente propagação, deverá observar as legislações em vigência no ordenamento pátrio que, embora não respalde plenamente seu inteiroarranjo, servem para regulamentá-la enquanto não lhe é criada uma lei específica ou um entendimento que vigore plenamente em todo território nacional.

Por derradeiro, a quebra da confidencialidade do conteúdo armazenado no aplicativo pela autoridade policial e sua utilização como prova processual exigem o requerimento e a concessão prévia da autoridade judicial, evitando que a prova seja posteriormente inadmitida ou eive por derivação as demais provas dela decorrentes.

É importante frisar que, na prisão em flagrante, é possível apreender o aparelho telefone juntamente com o conduzido, entretanto, o acesso aos dados e as conversas nele armazenados só pode ser permitido por ordem judicial, devido à proteção constitucional garantida pelo sigilo comunicacional e pela privacidade do indivíduo que dela faz uso. No tocante a busca 
e apreensão no domicilio do investigado, caso encontrado aparelho móvel, não há necessidade de nova ordem judicial, sendo o mandado de busca e apreensão suficiente para acessaro aplicativo WhatsApp e demais informações nele armazenadas.

Logo, conclui-se que, a partir da decisão do Habeas Corpus n. 51.530/RO, pela $6^{\mathrm{a}}$ Turma do Superior Tribunal de Justiça, que atendeu os ditames constitucionais, garantindo os direitos expressos na Constituição Federal, verificou-se maior tendência da Corte Superior em proferir decisões neste entendimento.

Assim, apesar do Tribunal de Justiça de Santa Catarina entender não haver violação de direitos e garantias constitucionais e que os dados possam ser acessados sem autorização judicial, observa-se que nos casos em que se recorre das decisões proferidas, há grande probabilidade do Superior Tribunal de Justiça anular as provas colhidas sem autorização, o que leva ao desentranhamento das provas nulas dos autos, podendo ensejar na extinção do processo, em razão da ilicitude das provas angariadas.

Em síntese, verifica-se que o melhor, neste momento, em termo de admissibilidade e proteção contra futura nulidade dos autos, é realizar requerimento a autoridade judicial antes de acessar o aparelho telefônico do investigado ou flagranteado. Por fim, provavelmente, as referidas decisões divergentes ensejem no futuro análise da matéria constitucional pelo Supremo Tribunal Federal, objetivando resolver as discrepâncias processuais vinculadas no meio judiciário, em face dos entendimentos diversos e decisões contrárias proferidas.

\section{REFERÊNCIAS}

BRANCO, Paulo Gustavo Gonet. Direitos fundamentais em espécie. Direito à liberdade e à vida Privada. In: BRANCO, Paulo Gustavo Gonet; MENDEZ, Gilmar Ferreira (org.). Curso de direito constitucional. 10. ed. São Paulo: Saraiva, 2015.

BRASIL. Constituição República Federativa do Brasil (1988). Brasília, DF: Senado Federal, 1988. Disponível em:http://www.planalto.gov.br/ccivil_03/constituicao/constituicao.htm. Acesso em: 02 nov. 2017. 
BRASIL. Lei n. 9.296, de 24 de julho de 1996. Regulamenta o inciso XII, parte final, do art. $5^{\circ}$ da Constituição Federal. Diário oficial da União. Brasília, DF, 25 jul. 1996. Disponível em: http://www.planalto.gov.br/ccivil_03/Leis/L9296.htm. Acesso em: 01 set. 2018.

BRASIL. Lei n. 12.965, de 23 de abril de 2014. Estabelece princípios, garantias, direitos e deveres para o uso da Internet no Brasil. Diário oficial da União. Brasília, DF, 24 abr. 2014. Disponível em: http://www.planalto.gov.br/ccivil_03/_Ato2011-2014/2014/ Lei/L12965.htm. Acesso em: 01 set. 2018.

BRASIL. Superior Tribunal de Justiça. Informativo n⿳0 593. Relator: Ministro Ribeiro Dantas. Diário da Justiça Eletrônico. Brasília, 9 nov. 2016b. Disponível em: http:// www.dizerodireito.com.br/2017/01/informativo-comentado-593-stj.html. Acesso em: 02 nov. 2017.

BRASIL. Superior Tribunal de Justiça. Penal. Processual Penal. Recurso em Habeas Corpus no 51.531 - RO (2014/0232367-7). Recorrente Leri Souza e Silva. Recorrido Ministério Público do Estado de Rondônia. Relator: Ministro Nefi Cordeiro. Brasília, DF, 19 de abril de 2016. Diário Judicial Eletrônico. Brasília, 9 maio 2016c. Disponível em: https://ww2.stj.jus.br/processo/revista/documento/mediado/?componente=ITA\&sequencial $=1497056 \&$ num_registro $=201402323677 \&$ data $=20160509 \&$ formato=PDF. Acesso em: 26 julho 2018 .

BRASIL. Superior Tribunal de Justiça. Recurso em Habeas Corpus n ${ }^{\circ}$ 73998. Recorrente: Luan Willian Domingos. Recorrido: Ministério Público do Estado de Santa Catarina. Relator: Ministro Joel Ilan Paciornik. Brasília, DF, 6 de fevereiro de 2018b. Diário Judicial Eletrônico. Brasília, 19 fev. 2018. Disponível em: http:/www.portaljustica.com.br/acordao/2098324. Acesso em: 8 ago. 2018.

BRASIL. Superior Tribunal de Justiça. Processual Penal. Recurso Ordinário em Habeas Corpus $n^{\circ}$ 77232/SC 2016/0270659-2. Recorrente: Yanka Guerra Torcatto. Ministério Público do Estado de Santa Catarina. Relator: Ministro Felix Fischer. Brasília, DF, 3 de outubro de 2017. Revista Eletrônica da Jurisprudência, Brasília, 16 out. 2017c. Disponível em: http://www.portaljustica.com.br/acordao/2072750. Acesso em: 12 maio 2018.

BRASIL. Superior Tribunal de Justiça. Recurso em Habeas Corpus n ${ }^{\circ} 89.385$ - SP, processo $n^{\circ}$ 2046110-33.2017.8.26.0000, 6 ${ }^{\text {a }}$ Turma. Leonardo de Oliveira Monteiro (preso). Ministério Público do Estado de São Paulo. Relator: Min. Rogerio Schietti Cruz. Brasília, DF, 16 de agosto de 2018c. Revista Eletrônica, Brasília, 28 ago. 2018. Disponível em: https://ww2.stj.jus.br/processo/revista/documento/mediado/?componente $=$ ITA\&sequencial $=1740088 \&$ num_registro $=201702394438 \&$ data $=20180828 \&$ formato=PDF. Acesso em: 2 set. 2018.

BRASIL. Superior Tribunal de Justiça. Penal e Processo Penal. Recurso em Habeas Corpus no 89.981 - MG (2017/0250966-3). Recorrente: Junior Guedes Ferreira. Recorrido: Ministério Público do Estado de Minas Gerais. Ministro Reynaldo Soares da Fonseca. Brasília, DF, 5 de dezembro de 2017. Revista Eletrônica da Jurisprudência, Brasília, 13 dez. 2017b. Disponível em: https://ww2.stj.jus.br/processo/revista/documento/mediado/?componente=ITA\&sequencial=1663002\&num_reg. Acesso em: 12 maio 2018.

BRASIL. Superior Tribunal de Justiça. Recurso Especial no 1675501/MG, Recurso Especial 2017/0136234-5. Ministro Sebastião Reis Júnior. Revista Eletrônica da Jurisprudência. Brasília, 27 out. 2017a. Disponível em: http://www.stj.jus.br/SCON/ jurisprudencia/toc.jsp?livre $=\mathrm{As}+$ instancias + ordinarias + contrariaram $+\mathrm{a}+$ juri. Acesso em: 02 nov. 2017. 
CAPEZ, Fernando. Curso de direito penal: legislação penal especial. 12. ed. São Paulo: Saraiva, 2017. v. 4. Disponível em: http://www.academia.edu/33647819/_Curso de_Direito_Penal_-_Vol._4_-_Legisla\%C3\%A7\%C3\%A3o_Penal_Especial_ 2017 _Fernando_Capez.p. $\overline{\text { df. }}$. Acesso em: 28 set. 2018.

GONÇALVES, Victor Hugo Pereira. Marco civil da internet comentado. São Paulo: Atlas, 2017. Disponível em: https://minhateca.com.br/RHAHU/2017+NOVIDADES/2017/*23Marco+Civil+da+Internet+Comentado+(2017)+-+Victor+Hugo+P.+Gon*c3*a7alves,1120529904.pdf. Acesso em: 02 nov. 2017.

LIMA, Renato Brasileiro de. Legislação criminal especial comentada: volume único. 4. ed. Salvador: Juspodivm, 2016. Disponível em: https://minhateca.com.br/Italo.Salgado/ Documentos/Direito+Penal/Legisla*c3*a $7 *$ c3*a3o+Criminal+Especial+Comentada+Renato+Brasileiro+de+Lima++2016+4ed,902606648.pdf. Acesso em: 02 nov. 2017.

LOPES JUNIOR, Aury. Direito processual penal e sua conformidade constitucional. 3. ed. Rio de Janeiro: Editora Lumen Juris, 2008.

NOVELINO, Marcelo. Direito constitucional. 4. ed. Rio de Janeiro: Forense, São Paulo: Método, 2010.

NUCCI, Guilherme de Souza. Interceptação Telefônica. In: NUCCI, Guilherme de Souza. Leis penais e processuais penais comentadas. 9. ed. Rio de Janeiro: Forense, 2016. v. 2.

OLIVEIRA, Eugênio Pacelli de. Curso de processo penal. 19. ed. São Paulo: Editora Atlas, 2015.

SANTA CATARINA (Estado). Tribunal de Justiça de Santa Catarina. Apelação Criminal n ${ }^{\circ}$ 0006810-29.2016.8.24.0020. Apelante: Rariton Albino de Faria. Apelado: Ministério Público do Estado de Santa Catarina. Relator: Desembargadora Salete Silva Sommariva. Florianópolis, 10 de julho de 2018a. Jurisprudência Catarinense. Florianópolis, 13 jul. 2018. Disponível em: http://busca.tjsc.jus.br/jurisprudencia/html. do?q=WhatsApp\&only_ementa=\&frase $=\& \mathrm{id}=$ AABAg7AAEAAMZdgAAJ\&categoria=acordao_5. Acesso em: 25 jul. 2018.

SANTA CATARINA (Estado). Tribunal de Justiça de Santa Catarina. Habeas Corpus n. 4007130-71.2016.8.24.0000. Relator: Desembargador Ernani Guetten de Almeida. Orgão Julgador: Terceira Câmara Criminal. Julgado em 30 de agosto de 2016a. Jurisprudência Catarinense. Florianópolis, 2 de set. 2016. Disponível em:

http://busca.tjsc.jus.br/jurisprudencia/html.do?q= HABEAS CORPUS. TRAFICO DE ENTORPECENTES E ASSOCIACAO PARA O TRAFICO. SUSTENTADA NULIDADE DE PROVAS OBTIDAS EM CONVERSAS POR APLICATIVO DE CELULAR (WHATSAPP)\&only; ementa=\& frase;=\&id=AABAg7AADAAGmmmAAE\&categoria=acordao_5. Acesso em: 02 nov. 2017.

SARLET, Ingo Wolfgang. Direitos fundamentais em espécie: $O$ direito à vida privada (privacidade e intimidade). In: SARLET, Ingo Wolfgang; MARINONI, Luiz Guilherme; MITIDIERO, Daniel. Curso de direito constitucional. 4. ed. São Paulo: Saraiva, 2015.

Recebido em: 28/04/2019

Aprovado em: 28/06/2019 